\title{
DETECTION AND ESTIMATION OF DIFFERENT COMPONENTS OF GENETIC VARIABILITY (ADDITIVE, DOMINANCE AND EPISTASIS) UNDER STRESS AND NON-STRESS CONDITIONS IN BREAD WHEAT \\ 1- ESTIMATION OF GENETIC COMPONENTS UNDER TWO LEVELS OF NITROGEN FERTILIZATION IN TWO BREAD WHEAT CROSSES
}

\author{
H. A. Dawwam ${ }^{(1)}$, F. H. Hendawy ${ }^{(1)}$, M. A. G. Abo Shereif ${ }^{(2)}$ \\ and Mona M. M. Serag EI-din ${ }^{(1)}$ \\ (1) Crop sci. Dep., Faculty of Agric., Menoufia University, Egypt. \\ (2) Wheat Research Department, Agriculture Research Center, Egypt.
}

Received: Mar. 21, 2016

Accepted: May 26,2016

\begin{abstract}
This investigation aimed to study the potentiality of heterosis expression, heritability, expected genetic advance, nature of gene actions and potance ratio for some quantitative traits (grain yield and its contributory characters, heading date and plant height) in two bread wheat crosses Sids $1 \times$ Gemmeiza 5 and Gemmeiza $9 \times$ Sids 4 were chosen for the percent study on the base of wide variability. Six populations $\left(P_{1}, P_{2}, F_{1}, F_{2}, B C_{1}\right.$ and $\left.B C_{2}\right)$ were used to estimate genetic parameters under two levels of nitrogen fertilization (35 kg N/fed and $70 \mathrm{~kg} \mathrm{n} / \mathrm{fed}$ ).

The results can be summarized as follows:

1. The hybrid combination Sids $1 \times$ Gemmeiza 5 was detected to be the highest cross showed significant useful heterosis for grain yield per plant (37.58\% and $76.11 \%$ ) under $35 \mathrm{~kg} . \mathrm{n}$. If and $70 \mathrm{~kg} . \mathrm{N} . / \mathrm{f}$, respectively.

2. Inbreeding depression values were found to be highly significant in most cases in the two crosses under investigation.

3. The $F_{2}$-deviations $\left(E_{1}\right)$ were significant for plant height and number of spikelets / main culm spike for all crosses under the both of nitrogen fertilization levels. Also backcross-deviations $\left(E_{2}\right)$ were found to be significant for heading date, main culm spike length, number of spikelets / main culm spike and number of kernels per spikelet under the two levels of nitrogen fertilization.

4. The additive gene effects (a) were found to be significant for heading date, plant height and 1000 grains weight for all crosses under investigation under the two levels of nitrogen fertilization.

5. Dominance gene effects (d) were found to be significant in the two crosses for number of spikelets $/$ main culm spike under $35 \mathrm{~kg} . \mathrm{N}$./f only.

6. The three epistatic types additive $x$ additive, additive $x$ dominance and dominance $x$ dominance were found to be significant for most traits under investigation.

7. High heritability estimates in broad sense were detected for nearly all traits studied. high estimates of narrow sense heritability were found for all crosses for heading date, plant height, number of spikes per plant, main culm spike length, number of kernels per spikelets, number of kernels per main culm spike and grain yield per plant under $35 \mathrm{~kg} . \mathrm{N}$./fed.

8. High genetic advance under selection was found to be associated with high narrow sense heritability estimates for number of spikes per plant and grain yield per plant for all crosses under 35 kg.N./f.
\end{abstract}




\section{Dawwam, et al.,}

9. The breeder can use cross Sids $1 \times$ Gemmeiza 5 in breeding programs that it has high heterosis for yield character and its components and high genetic advance under selection was found to be associated with high narrow sense heritability estimates for number of spikes per plant and grain yield per plant.

Key words: Wheat, Gene action, Heterosis, Heritability, Genetic advance, Additive, Dominance, Six parameters model.

\section{INTRODUCTION}

Bread wheat is the most important widely adapted consumed food cereal in Egypt. Therefore, wheat breeders are concentrating their efforts to improve the yield potential of wheat to meet the future goals by developing new cultivars with desirable genetic makeup. Growing wheat under low nitrogen fertilizer become an objective in Egypt. Nitrogen fertilizer is an important factor in wheat production package. The choice of selection and breeding procedures for genetic improvement of any crop is largely dependent on the knowledge of type and relative amount of genetic component and the presence of non-allelic interaction for different characters in the plant materials under investigation.

Six parameters analysis provides information on the relative importance of average effects of the genes (additive effects), dominance deviations, and effects due to non-allelic genetic interactions. This helps in determining genotypic values of the individuals and, consequently, the mean genotypic values of families and generations. Generation mean analysis, is a simple and useful technique for estimating gene effects of polygenic trait. Its greatest merit goes to the ability of estimating epistatic gene effects (additive $x$ additive (aa), dominance $x$ dominance (dd) and additive $x$ dominance (ad)), (Singh and Singh, 1992) to be used for the improvement of agronomic traits in wheat.

Most of the designs used in estimating the genetic components of variation assume the absence of epistasis. Most of the information on the genetic analysis is biased due to the presence of epistasis. However, epistatic interactions have frequently been reported by many scientists in wheat (Singh and Singh, 1976, Ketata et al 1976, Singh 1981, Comber 2001and others). Among all the designs available for estimation of gene action, the relationships illustrated by Gamble (1962) were considered one of the important models provide the different components of variation i.e additive, dominance and epistasis. In self-pollinated species like wheat, epistasis is perhaps more important to breeders than dominance, because the latter is necessarily ephemeral in such species.

The objectives of the present study are to establish: (1) The potentiality of heterosis expression for grain yield and its contributory characters, heading date and plant height; (2) Estimation of different components of variation i.e. additive, dominance and epistasis controlling traits studied. (3) The genetical behavior, heritability and expected genetic advance under selection for grain yield and some agronomic traits in the two crosses, i.e. Sids $1 \times$ Gemmeiza 5 and Gemmeiza $9 \times$ Sids 4 under two levels of nitrogen fertilization.

\section{MATERIALS AND METHODS}

This experiment was carried out at the Experimental Farm, Faculty of Agriculture, Menoufia University at Shebin El-Kom during the three successive seasons 2009 / 2010, 2010 / 2011 and 2011 / 2012 growing season. Four parental genotypes of bread wheat (Triticum aestivum L.) were chosen regarding their agronomic performance. 
These genotypes are:, Sids 1, Sids 4, Gemmeiza 5 and Gemmeiza 9.In the first season (2009-2010), the four parental genotype were intercrossed (by hand emasculation and pollination techniques) to produce two $F_{1}$ crosses, (I) Sids $1 \mathrm{X}$ Gemmeiza 5 and (II) Gemmeiza 9 X Sids 4. In the second season (2010/2011), the hybrid seeds were sown and the $F_{1}$ plants of each cross were back crossed to their respective parents to produce the two backcrosses $\mathrm{BC}_{1}$ and $\mathrm{BC}_{2}$. Meanwhile, $\mathrm{F}_{1}$ plants were self-pollinated to produce $F_{2}$ seeds.

In the third growing season (2011/2012), the six populations $\mathrm{P}_{1}, \mathrm{P}_{2}, \mathrm{~F}_{1}, \mathrm{~F}_{2}, \mathrm{Bc}_{1}$ and $\mathrm{Bc}_{2}$ of each cross were sown in a randomized complete block design with three replicates under two different levels of nitrogen fertilization ( $35 \mathrm{~kg} \mathrm{~N} / \mathrm{fed}$ [low level] and $70 \mathrm{~kg} \mathrm{~N} / \mathrm{fed}$ [recommended level]) using nitrogen as urea (46.5\% N/unit). Each block comprised 15 rows of $\mathrm{F}_{2}, \mathrm{Bc}_{1}$ and $\mathrm{Bc}_{2}$ and five rows of other three non-segregated populations. The experimental units consisted of single rows 3 meters long with $20 \mathrm{~cm}$. between rows, plants within rows were $10 \mathrm{~cm}$. apart allowing a total of 30 plants per row.

Data were recorded on individual guarded plants (60 plants for unsegregated generations, 90 plant in $\mathrm{Bc}_{1}$ and $\mathrm{Bc}_{2}$ and 120 plants in $F_{2}$ ) for the studied characters as follows: 1- Days to heading (days), recorded as number of days from sowing to first appearance of owns through the flag leaf sheaths. 2- Plant height $(\mathrm{cm})$, measured to the tips of the ear (awns excluded) of the main culm i.e. tallest tiller. 3- Number of spikes per plant. 4- Main culm spike length (cm). 5- Number of spikelets per main culm spike. 6- Number of grains per main culm spike. 7- Grain yield per main culm spike (gm.). 8-.Number of grains per spikelet. 91000-grain weight (gm.). 10- Grain yield per plant (gm.).The chemical and mechanical analysis of soil are presented in Table (2).

\section{Statistical procedures:}

The t-test was used to examine the existence of genetic variance between parental means. Statistical procedures used herein would only be computed if the $F_{2}$ genetic variance was found to be significant. A one tail " $F$ " ratio was used to examine the existence of the genetic variance within the $F_{2}$ population as follows:

$$
\mathrm{F}=\frac{\mathrm{VF}_{2}}{\mathrm{VE}}
$$

Where $\quad \mathrm{VE}=\frac{\mathrm{VP}_{1}+\mathrm{VP}_{2}+\mathrm{VF}_{1}}{3}$

The degree of freedom for this test was considered as infinity. If calculated " $F$ " ratio was equal to or larger than the tabulated ones, various biometrical parameters needed in this investigation would be computed. Heterosis $(\mathrm{H})$, was expressed as percent increase of the $F_{1}$ mean performance above the respective better parent, i.e. $\left(\overline{\mathrm{F}_{1}}-\overline{\mathrm{B} . \mathrm{P}}\right) / \overline{\mathrm{B} . \mathrm{P}} \times 100$. Inbreeding depression (I.d.) was measured as the average percent decrease of the $\overline{F_{2}}$ from the $\overline{\mathrm{F}}_{1}$. Inbreeding depression

$$
\text { (I.d.\%) }=\frac{\overline{F_{1}}-\overline{F_{2}}}{\overline{F_{1}}} \times 100 \cdot F_{2}-\text { deviation }\left(E_{1}\right)
$$
was calculated as the deviation of the $F_{2}$ mean performance from the average of $F_{1}$ and mid-parent value (Marani, 1968) . Deviation $\left(\mathrm{E}_{2}\right)$, was computed as the deviation of the two backcrosses performance from the $F_{1}$ and mid parent performances (Marani, 1968). The names, origin and pedigree of the four wheat cultivars used in this study in Table (1). 
Dawwam, et al.,

Table (1): The names, origin and pedigree of the four wheat cultivars used in this study.

\begin{tabular}{|c|c|c|l|}
\hline No & Cultivar & Origin & \multicolumn{1}{|c|}{ Pedigree } \\
\hline 1 & Sids 1 & Egypt & $\begin{array}{l}\text { HD2172/Pavon"S"//1158-57 Maya 74 "S"Sd46-4Sd-2Sd- } \\
\text { 1Sd-0Sd }\end{array}$ \\
\hline 2 & Sids 4 & Egypt & Maya“S”/Mon“S"/CMH74.A.592/3/CHZa157* \\
\hline 3 & Gemmeiza 5 & Egypt & Vee“S"/SWM6525 CGM4017-1GM-6GM-3GM-0GM \\
\hline 4 & Gemmeiza 9 & Egypt & $\begin{array}{l}\text { Ald“S”/Huac"S"//CMH74A.630/5X CGM4583-5GM-1GM- } \\
\text { 0GM }\end{array}$ \\
\hline
\end{tabular}

Table (2): Soil status at the Experimental Farm of Faculty of Agriculture, Menoufia University at Shebin El-Kom season 2011/2012.

\begin{tabular}{|c|c|}
\hline Characteristics & Analysis \\
\hline \multicolumn{2}{|c|}{ Chemical analysis } \\
\hline $\mathrm{EC}$ & 3.0 \\
\hline $\mathrm{pH}$ & 8.7 \\
\hline $\mathrm{N} \mathrm{ppm}$ & 27.3 \\
\hline $\mathrm{P} \mathrm{ppm}$ & 8.75 \\
\hline $\mathrm{K} \mathrm{ppm}$ & 36.25 \\
\hline \multicolumn{2}{|c|}{ Mechanical analysis } \\
\hline Find sand\% & 59.4 \\
\hline Silt \% & 10.5 \\
\hline Clay \% & 30.10 \\
\hline Soil texture & Clay \\
\hline
\end{tabular}

Nature and degree of dominance were determined by means of potence ratio method $(P)$ which can be defined as the average dominance of the whole gene set of one parent or the other (Peter and Frey, 1966). Nature of gene action i.e, $m=F_{2}$ generation mean. $\mathrm{a}=$ The pooled additive effect. $d=$ The pooled dominance effect. aa $=$ The pooled additive $\times$ additive epistatic effects. $\quad \mathrm{ad}=$ The pooled additive $\times$ dominance epistatic type. $\mathrm{dd}=$ The pooled dominance $\times$ dominance epistatic type was studied according to the relationships illustrated by Gamble (1962).Where: $m=F_{2}$ generation mean. $a=$ The pooled additive effect. $d=$ The pooled dominance effect. aa $=$ The pooled additive $\times$ additive epistatic effects. ad $=$ The pooled additive $\times$ dominance epistatic type. $d d=$ The pooled dominance $x$ dominance epistatic type. Heritability was estimated in both broad and narrow senses for $F_{2}$ generation, according to Mather's procedures (1949). $\mathbf{h}^{2}($ broad sense $)=\frac{1 / 2 \mathbf{D}+1 / 4 \mathbf{H}}{1 / 2 \mathbf{D}+1 / 4 \mathbf{H}+\mathbf{E}}$ $\mathbf{h}^{2}($ narrow sense $)=\frac{1 / 2 \mathbf{D}}{1 / 2 \mathbf{D}+1 / 4 \mathbf{H}+\mathbf{E}}$

Where:

$1 / 2 \mathrm{D}=2 \mathrm{VF}_{2}-\left(\mathrm{VBc}_{1}+\mathrm{VBc}_{2}\right), \quad 1 / 4 \mathrm{H}=\mathrm{VBc}_{1}+$ $\mathrm{VBc}_{2}-\left(\mathrm{VF}_{2}+\mathrm{VE}\right)$

$$
\text { and } \mathbf{V E}=\frac{\mathbf{V P}_{1}+\mathbf{V P}_{2}+\mathbf{V F}_{1}}{3}
$$

The predicted genetic advance under selection $(\Delta \mathrm{G})$ was computed according to Johnson et al. (1955). $\Delta G=K \cdot h^{2}$. $\sigma$ ph Where: $\mathrm{K}$ is the selection differential (which equals the value of 2.06 when selecting the highest $5 \%$ of the population). $h_{2}=$ heritability value in narrow sense and $\sigma$ ph $=$ phenotypic standard deviation of the $F_{2}$ 
generation. This genetic gain represented as percentage of the $F_{2}$ mean performance was also obtained following (Miller et al., 1958).

$\Delta \mathrm{G} \%=\frac{\Delta \mathrm{G}}{\overline{\mathrm{X}} \mathrm{F}_{2}} \times 100$

\section{RESULTS AND DISCUSSION}

The validity of the varietal differences and the genetic variance within $F_{2}$ populations of each cross for all traits studied i.e. heading date, plant height, number of spikes per plant, main culm spike length, number of spikelets / main culm spike, number of kernels per spikelet, number of kernels per main culm spike, 1000 grains weight, grain yield per main culm spike and grain yield per plant are presented in Table (3). Varietal differences in response to their genetic background were found to be significant in all characters studied in each of the two crosses i.e. I (Sids 1 x Gemmeiza 5), and II (Gemmeiza 9 x Sids 4) under investigation except grain yield per plant in first, second cross, number of spikes per plant in the second cross, grain yield per main culm spike and 1000-kernels weight in the first cross. Consequently, the various genetical parameters used in this investigation were estimated for all traits studied under $35 \mathrm{~kg} \mathrm{~N} / \mathrm{fed}$ of nitrogen fertilization.

Table (3): T-test for the differences between parents and F-test of significance of the genetic variance in $F_{2}$ populations for all traits studied in the two crosses under 35 and $70 \mathrm{~kg} \mathrm{~N} / \mathrm{fed}$ of nitrogen fertilization.

\begin{tabular}{|c|c|c|c|c|c|}
\hline \multirow{2}{*}{ Characters } & \multirow{2}{*}{$\begin{array}{c}\mathrm{Kg} \mathrm{N} / \\
\text { fed }\end{array}$} & \multicolumn{2}{|c|}{ Sids $1 \times$ gemmeiza 5} & \multicolumn{2}{|c|}{ Gemmeiza 9 x sids 4} \\
\hline & & T-test & F-test & T-test & F-test \\
\hline \multirow{2}{*}{ Days to heading } & 35 & ** & ** & ** & ** \\
\hline & 70 & ** & ** & ** & ** \\
\hline \multirow{2}{*}{ Plant height } & 35 & ** & $* *$ & ** & $* *$ \\
\hline & 70 & ** & ** & ** & ** \\
\hline \multirow{2}{*}{ Number of spikes per plant } & 35 & ** & ** & N.S & $\star *$ \\
\hline & 70 & N.S & ** & ** & ** \\
\hline \multirow{2}{*}{ Main culm spike length } & 35 & ** & ** & ** & ** \\
\hline & 70 & ** & ** & ** & ** \\
\hline \multirow{2}{*}{ Number of spikelets / main culm spike } & 35 & ** & ** & ** & ** \\
\hline & 70 & N.S & $* *$ & ** & $* *$ \\
\hline \multirow{2}{*}{ Number of kernels per spikelet } & 35 & $* *$ & $* *$ & * & $* *$ \\
\hline & 70 & ** & ** & ** & * \\
\hline \multirow{2}{*}{ Number of kernels per main culm spike } & 35 & ** & ** & $\star *$ & $\star * *$ \\
\hline & 70 & * & $* *$ & $\star *$ & $\star *$ \\
\hline \multirow{2}{*}{1000 grain weight } & 35 & N.s & $* \star$ & $\star *$ & $\star *$ \\
\hline & 70 & N.S & * & $\star *$ & * \\
\hline \multirow{2}{*}{ Grain yield per main culm spike } & 35 & N.s & $* *$ & ** & * \\
\hline & 70 & N.S & ** & ** & * \\
\hline \multirow{2}{*}{ Grain yield per plant } & 35 & N.S & $\star \star *$ & N.S & $* *$ \\
\hline & 70 & ** & $* *$ & N.s & $* *$ \\
\hline
\end{tabular}

*, ** Significant at 0.05 and 0.01 probability levels, respectively.

N.S Denotes insignificance at 0.05 and 0.01 probability 
Under $70 \mathrm{~kg} \mathrm{~N} / \mathrm{fed}$ nitrogen fertilization it was found to be significant for all characters studied in each of the two crosses except number of spikes per plant, number of spikelets per main culm spike, grain yield per main culm spike, grain yield per plant and 1000-grains weight in the first cross, grain yield per plant in the second cross. Consequently, the various genetical parameters used in this investigation were estimated for all traits studied. The existence of the significant genetic variability in $F_{2}$ populations in spite of the insignificant differences between the parental cultivars for the characters previously mentioned, may suggest that the genes of like effects were not completely associated in the parental cultivars i.e., these genes are dispersed (Mather and Jinks, 1982).

Means and variances of the six populations $\mathrm{P}_{1}, \mathrm{P}_{2}, \mathrm{~F}_{1}, \mathrm{~F}_{2}, \mathrm{Bc}_{1}$ and $\mathrm{Bc}_{2}$ for all traits studied in the two crosses under $35 \mathrm{~kg}$ $\mathrm{n} / \mathrm{fed}$ and $70 \mathrm{~kg} \mathrm{n} / \mathrm{fed}$ nitrogen fertilization are given in Table (4). Noticed that the means of all characters under investigation were high under $70 \mathrm{kgn} / \mathrm{fed}$ than $35 \mathrm{~kg}$ $\mathrm{n} / \mathrm{fed}$ of nitrogen fertilization in the two crosses.

\section{Heterosis:}

The expression of heterotic effect values for all traits in the two crosses studied is presented in Table (5). High positive values of heterosis would be of interest in most traits under investigation; however, for days to heading and plant height, high negative values would be useful from the wheat breeders point of view.

Regarding days to heading, at $35 \mathrm{~kg} / \mathrm{fed}$ of nitrogen fertilization highly significant negative useful heterosis was detected in the first cross (Sids $1 \times$ Gemmieza 5), and second cross (Gemmieza $9 \times$ Sids 4). Little or no heterosis for days to heading was previously found by El-Seidy and Hamada (2000) and Comber (2001). However, significant heterosis was previously detected by Hendawy et al., (2007 b), El-borhamy et al., (2008), Koumber (2011) and Marwa M. El-Nahas and Arab (2014). But in $70 \mathrm{~kg} / \mathrm{f}$ nitrogen fertilization significant negative useful heterosis was detected in all crosses. It also founded by El-Shaarawy and Morad (2011).

For plant height, useful heterosis toward shortness were found to be significant and highly significant in the second cross (Gemmieza $9 \times$ Sids 4) while the first cross (Sids $1 \times$ Gemmieza 5) showed highly significant positive heterosis. Regarding to Akhtar and Ibrahim (2005) and El-Shaarawy and Morad (2011).

As for number of spikes per plant, under $35 \mathrm{~kg} / \mathrm{f}$ nitrogen fertilization, the second cross (Gemmieza $9 \times$ Sids 4), was found to have significantly more spikes than its better parent Sids 4. No useful heterosis was found in the first cross under $70 \mathrm{~kg} / \mathrm{f}$ nitrogen fertilization. Heterotic effects for number of productive tillers per plant were also found by Bayoumi (2004), Mekhamer (2009) and El-Shaarawy and Morad (2011).

The two wheat crosses under investigation did not show any useful heterotic effects for number of spikelets per spike and number of kernels per spikelet under 35 and $75 \mathrm{~kg} / \mathrm{f}$ nitrogen fertilization. That also founded by Akhtar and Ibrahim (2005). However, significant positive heterosis for number of spikelets per spike was reported by Mekhamer (2009).

With regard to number of kernels per main culm spike the 35 and $75 \mathrm{~kg} / \mathrm{f}$ nitrogen fertilization, highly significant positive heterotic effect was detected in all crosses. Significant heterosis was also found by Darwish and Ashoush (2003), Bayoumy (2004) and Mekhamer (2009).

As for 1000-grain weight, highly significant positive heterotic effect was detected in all crosses under both nitrogen 


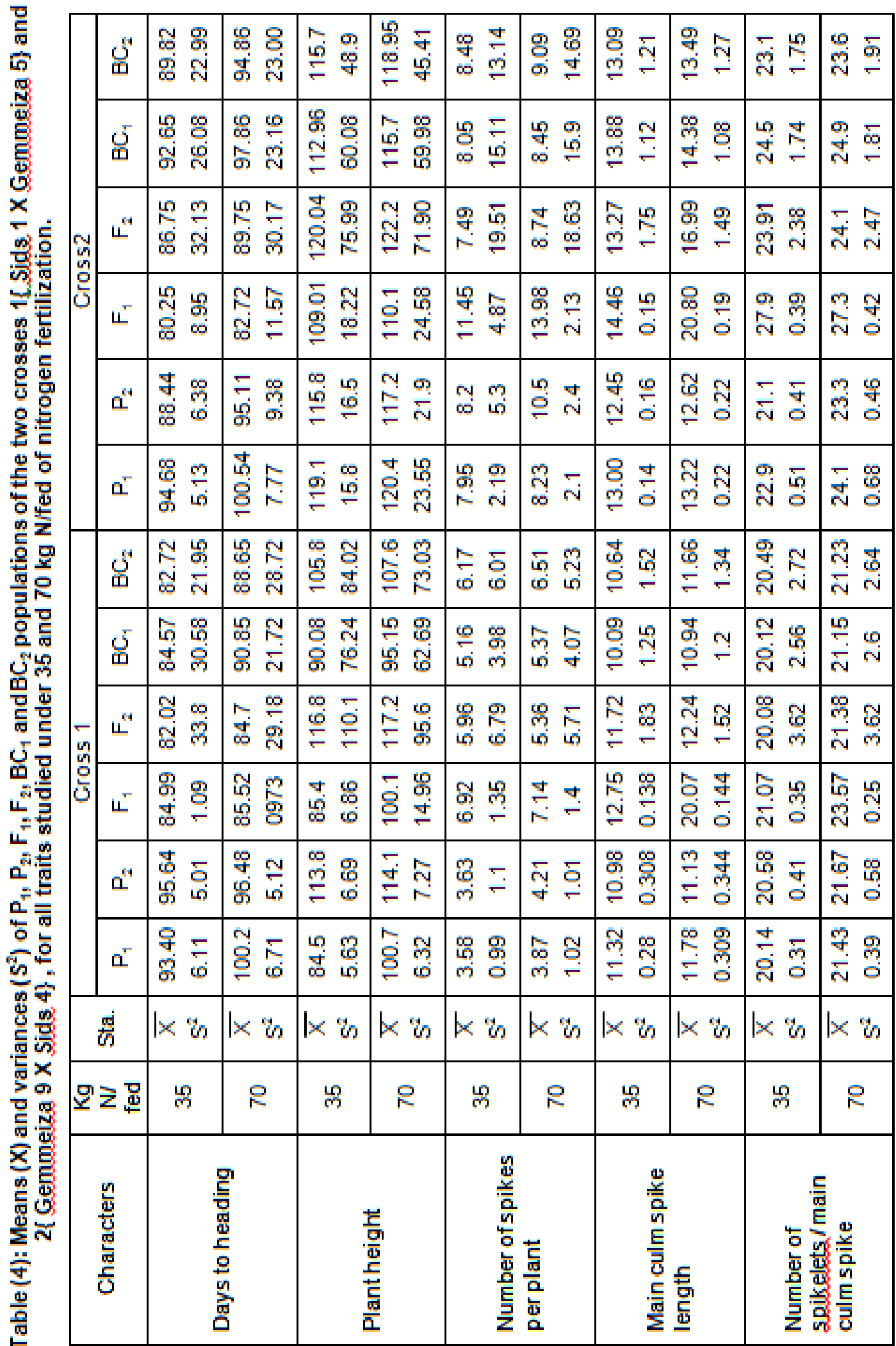




\begin{tabular}{|c|c|c|c|c|c|c|c|c|c|c|}
\hline 苗 & $\begin{array}{ll}\Omega & 3 \\
N & 0\end{array}$ & 员 & 焉 & $\begin{array}{ll}8 \\
\mathrm{O}\end{array}$ & 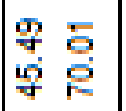 & 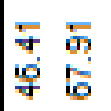 & 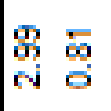 & $\begin{array}{ll}\Re & ? \\
0 & 0\end{array}$ & 屋 & बूल \\
\hline 㽞 & Ny & గ్ర & $\begin{array}{ll}19 & \infty \\
& 8 \\
& 8 \\
\end{array}$ & 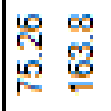 & 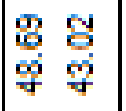 & 量 & 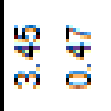 & $\begin{array}{l}\text { 号 } \\
\text { ल } \\
\text { ल }\end{array}$ & 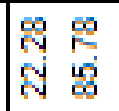 & $\begin{array}{l}\text { लै } \\
\text { लू } \\
\text { ले }\end{array}$ \\
\hline$\ddot{H}^{\prime \prime}$ & $\left|\begin{array}{cc}0 & 0 \\
& 0 \\
& 0\end{array}\right|$ & 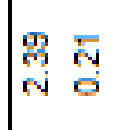 & 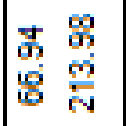 & 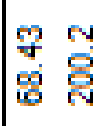 & 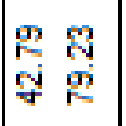 & 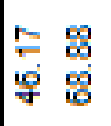 & 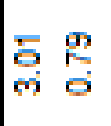 & \begin{tabular}{ll}
$\mathrm{N}$ & \multicolumn{1}{c}{} \\
$\mathrm{c}$ & 0 \\
$\mathrm{~m}$ & 0
\end{tabular} & 荥 & 今心 \\
\hline "і & 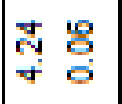 & \begin{tabular}{ll}
8 & \multicolumn{3}{|c}{} \\
$\dot{\sigma}$ & 0
\end{tabular} & 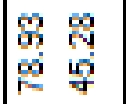 & 学 8 & 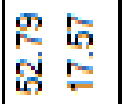 & 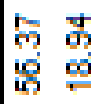 & ণิ & 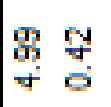 & 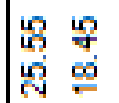 & 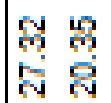 \\
\hline$\alpha^{r+4}$ & 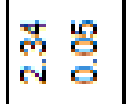 & $\begin{array}{ll} & 5 \\
& 0\end{array}$ & 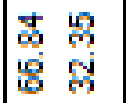 & 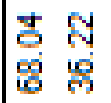 & 每空 & 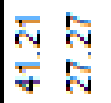 & 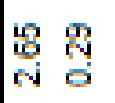 & \% & 哭 ले & 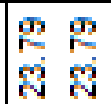 \\
\hline $\mathrm{a}^{-}$ & 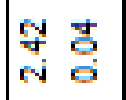 & 电 & 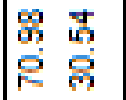 & 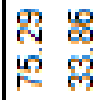 & 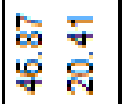 & 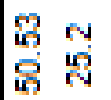 & $\begin{array}{c}\bar{N} \\
\bar{\aleph} \\
\bar{\sigma}\end{array}$ & 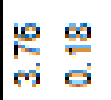 & 包 & 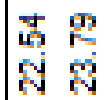 \\
\hline 苗 & $\left|\begin{array}{ll}\bar{n} & 9 \\
\overline{0} & 0 \\
& 0\end{array}\right|$ & 峞 & $\begin{array}{ll} & \circ \\
\sigma & \stackrel{2}{2}\end{array}$ & 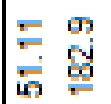 & 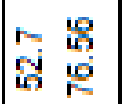 & 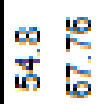 & 罣 & 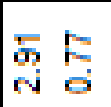 & 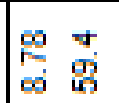 & $\mid \begin{array}{l}\text { 芯 } \\
\text { के } \\
\text { के }\end{array}$ \\
\hline 品 & 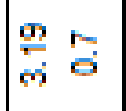 & $\begin{array}{ll}\text { N̂ } \\
\text { ल : } \\
\text { ल }\end{array}$ & 응 & 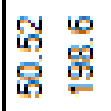 & \begin{tabular}{ll}
$=$ & $\infty$ \\
\hdashline & 0 \\
\hdashline & 0 \\
\hdashline
\end{tabular} & 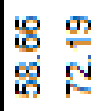 & $\begin{array}{ll}\mathscr{0} & 9 \\
& 0 \\
\end{array}$ & $\begin{array}{ll}\bar{\sigma} & \bar{\infty} \\
\mathrm{N} & 0\end{array}$ & 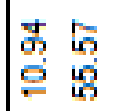 & 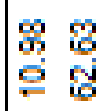 \\
\hline$\ddot{H}^{\prime \prime}$ & 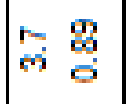 & $\begin{array}{ll}N & \mathscr{O} \\
& 0\end{array}$ & 空 & 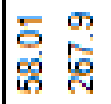 & 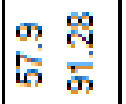 & $\begin{array}{ll}10 & 0 \\
5 & 8 \\
8 & 5 \\
8 & 5\end{array}$ & 总 뇽 & 总 & 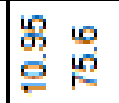 & 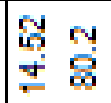 \\
\hline ü & 今ָ & 芯 & 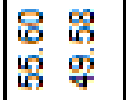 & 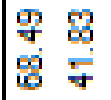 & 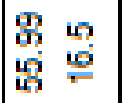 & 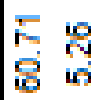 & 岁 & 邑 & $\stackrel{9}{=}$ & 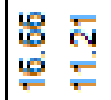 \\
\hline$\alpha^{r 4}$ & 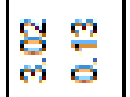 & $\underset{\mathrm{c}}{\mathrm{C}}$ & 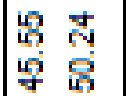 & $\begin{array}{l}\text { 岕 } \\
\text { ơ }\end{array}$ & 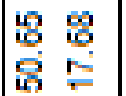 & 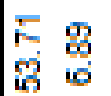 & Nু & 寸 & $\mid \begin{array}{ll}g & \hat{b} \\
\dot{0} & \dot{v}\end{array}$ & $\begin{array}{l}\text { io } \\
=\end{array}$ \\
\hline$a^{-}$ & 岕 & 罗 & r & $\begin{array}{ll}\text { 点 } \\
\text { 量 } \\
\text { 品 }\end{array}$ & 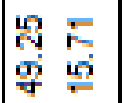 & 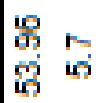 & 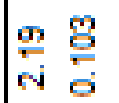 & 㝵 & 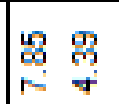 & $\begin{array}{cc}\infty \\
0 \\
\infty\end{array}$ \\
\hline 焉 & 队 "艹 & $\times$ " w & 队 " & $\mid \times$ " क & $\times$ " & $x$ " * & × " & $k$ on & k" " & k" क \\
\hline 之 & 虫 & 우 & 쏭 & 우 & $\stackrel{\mu}{\rho}$ & 우 & 㟧 & 우 & 㟧 & 운 \\
\hline 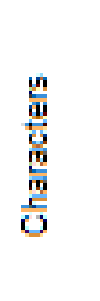 & \multicolumn{2}{|c|}{ 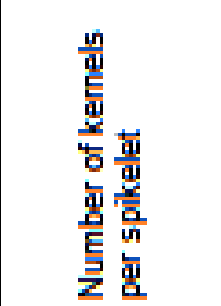 } & \multicolumn{2}{|c|}{ 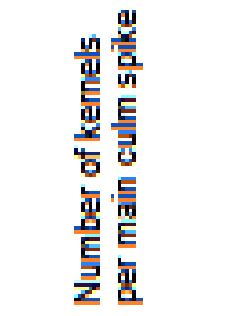 } & \multicolumn{2}{|c|}{ 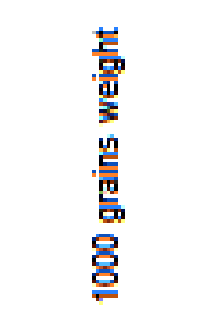 } & \multicolumn{2}{|c|}{ 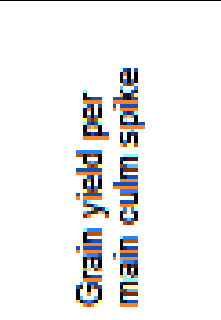 } & \multicolumn{2}{|c|}{ 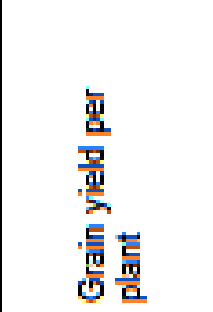 } \\
\hline
\end{tabular}




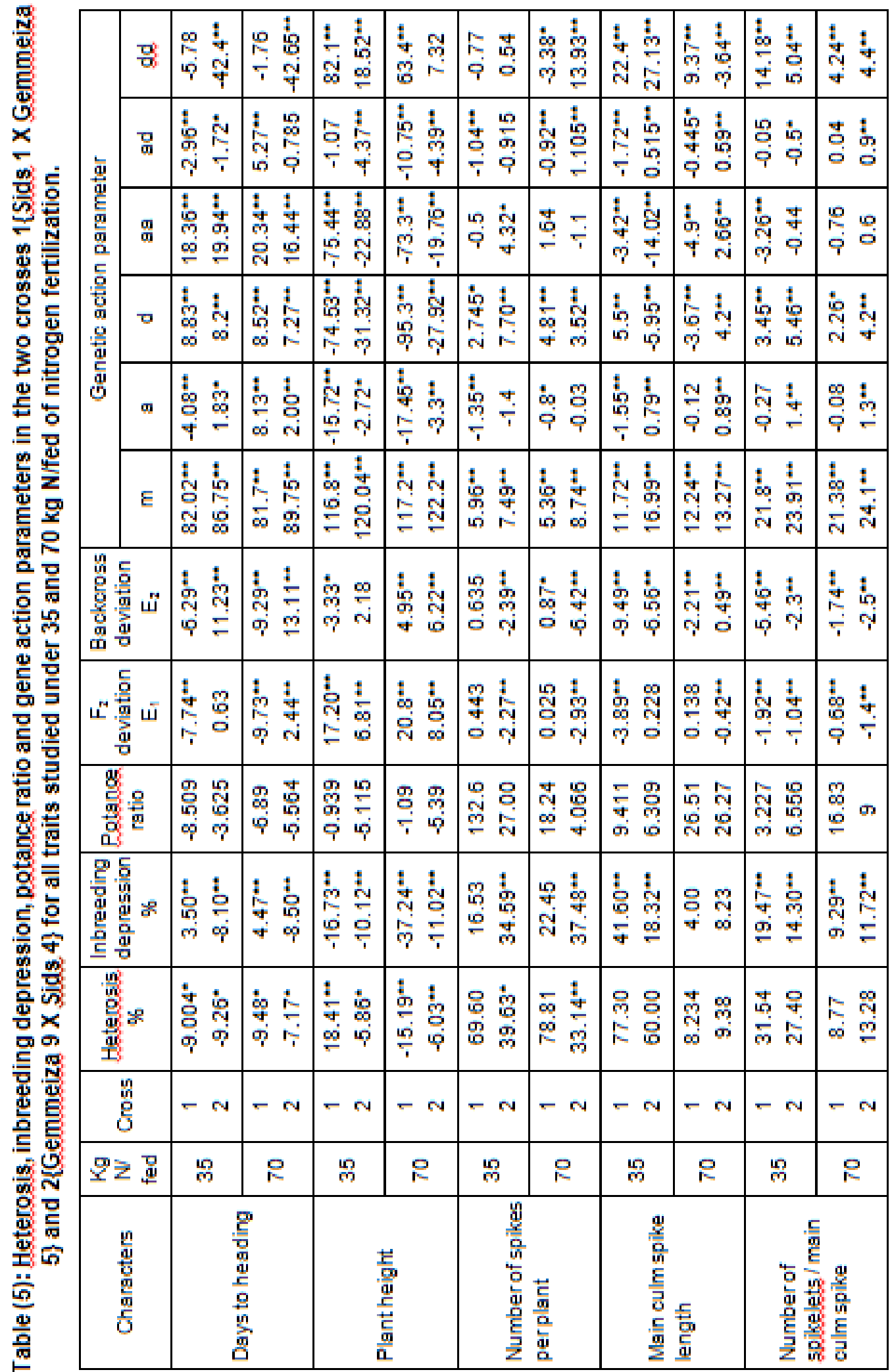


fertilizations. Similar results were previously reported by Sharief et al., (2006), Hendawy et al., (2007 b), El-Borhamy et al., (2008) and Mekhamer (2009).

Concerning, grain yield per main culm spike, no useful heterotic effect was found in the two crosses studied under $35 \mathrm{~kg} / \mathrm{f}$ nitrogen fertilization and the same in $70 \mathrm{~kg} / \mathrm{f}$ nitrogen fertilization. However, significant heterosis for yield was previously found by Comber (2001).

As for grain yield per plant, highly significant positive heterotic effect was detected in all crosses for both nitrogen fertilizations. Significant heterosis was also found by Bayoumy (2004), Sharief et al., (2006) and Mekhamer (2009). On the other hand no useful heterosis founded by $\mathrm{El}$ Seidy and Hamada (2000).

\section{Inbreeding depression:}

Inbreeding depression is measured as the percent deviation of $F_{2}$ from $F_{1}$ mean performance. The estimation of inbreeding depression values are presented in Table (5). Inbreeding depression values were found to be highly significant in most cases in the two crosses under 35 and $70 \mathrm{~kg} / \mathrm{f}$ nitrogen fertilization except number of spikelets per plant, number of kernels per spikelets, 1000 grain weight and grain yield per plant in first cross, grain yield per main culm spike in all crosses. Under $35 \mathrm{~kg} / \mathrm{f}$ nitrogen fertilization, number of spikes per plant, main culm spike length, number of kernels per spikelet and grain weight per plant in the first cross, grain yield per main culm spike in all crosses .

On the contrary, this expectation was not fulfilled in some cases, where insignificant heterosis and significant inbreeding depression main culm spike length and number of spikelets per main culm spike in all crosses, number of kernels per spikelet in second cross, and grain yield per plant and
1000 grain weight in first under $35 \mathrm{~kg} / \mathrm{f}$ nitrogen fertilization. For $70 \mathrm{~kg} / \mathrm{f}$ nitrogen fertilization insignificant heterosis and significant inbreeding depression in number of spikelets per main culm spike in all crosses, number of grains per spikelet in the second cross. Similar contradiction was also reported by Esmail and Kattab (2002). The contradiction between heterosis and inbreeding depression estimates could be due to the presence of linkage between genes in these materials.

\section{Potance ratio:}

Potence ratio for all traits studied in the two crosses under investigation are given in Table (5). The average degree of dominance as indicated by potence ratio revealed the existence of over dominance towards the high parent for number of spikes per plant, main culm spike length, number of kernels per spikelets and number of kernels per main culm spike for all crosses under the two levels of nitrogen fertilization except for 1000 grains weight and grain weight per plant in the first cross, while it was towards the lower parent for days to heading, 1000 grains and grain weight per plant for all crosses under the two levels of nitrogen fertilization except in the first cross under 35 $\mathrm{kg} \mathrm{N} / \mathrm{fed}$ and plant height for all crosses under the two levels of nitrogen fertilization.

Partial dominance towards the higher parent was found for grain weight per main culm spike in the first cross under $35 \mathrm{~kg}$ $\mathrm{N} /$ fed only. However, partial dominance towards the lower parent were found for plant height, 1000 grains weight and grain weight per plant in the first cross under $35 \mathrm{~kg}$ $\mathrm{N} / \mathrm{fed}$ only. Similar results were also found by Comber (2001) and Ghanem (2008).

\section{4. $F_{\mathbf{2}}$ - performance $\left(E_{1}\right)$ :}

$\mathrm{F}_{2}$ mean performances for all traits studied in the two crosses under investigation are given in Table (5). Under $35 \mathrm{~kg} / \mathrm{fed}$ nitrogen fertilization $F_{2}$ mean 
performance was found to deviate significantly from the average of the $F_{1}$ and mid-parent value $E_{1}$ for days to heading, plant height, main culm spike length, number of spikelet per main culm spike, number of kernels per main culm spike and 1000-grain weight in all crosses under investigation. Number of spikes per plant and grain yield per plant, number of kernels per spikelets and grain yield per main culm spike in the second cross. The highly expressive $F_{2^{-}}$ deviation $\left(E_{1}\right)$ would indicate the presence of epistasis in the inheritance of these traits.

Under $70 \mathrm{~kg} \mathrm{~N} / \mathrm{fed}$ of nitrogen fertilization $\mathrm{F}_{2}$ mean performance was found to deviate significantly from the average of the $F_{1}$ and mid-parent value $E_{1}$ for days to heading, plant height, number of spikelets per main culm spike, grain weight per plant, number of spikes per plant and 1000 grains weight in the first and second cross, main culm spike length, number of grains per spikelet, grain weight per main culm spike and number of grains per main culm spike in the second cross. The highly expressive $F_{2}$-deviation $\left(E_{1}\right)$ would indicate the presence of epistasis in the inheritance of these traits. These results were found also by Esmail and Kattab (2002) and Ghanem (2008)

\section{Backcross performance $\left(E_{2}\right)$ :}

Backcross performance for the tenth traits studied in the two crosses under investigation are presented in Table (5). When no effects of epistasis are assumed, backcross performance would be expected to be near the average of $F_{1}$ and recurrent parent performance. Appreciable deviation from this expected value, however, will be observed if epistasis is found to be operated in the inheritance of the trait in yield. Under $35 \mathrm{~kg} / \mathrm{f}$ nitrogen fertilization Backcross deviation $\left(E_{2}\right)$ was also found to be significant for days to heading, main culm spike length, number of kernels per spikelet and number of spikelets per main culm spike, number of kernels per main culm spike and number of kernels per main culm spike in all crosses, number of spikes per plant, grain yield per main culm spike and grain yield per plant in the second cross, plant height and 1000 grains weight in the first cross. The $F_{2}$ deviation $\left(E_{1}\right)$ was accompanied by backcross deviation $E_{2}$ in twenty nine cases Table (5) and that would ascertained the presence of epistasis in such large magnitude as to warrant great deal of attention in wheat breeding programs. Under $70 \mathrm{~kg} \mathrm{~N} / \mathrm{fed}$ nitrogen fertilization it was found to be significant for all traits in all crosses except number of grains per main culm spike and 1000 grains weight in the first cross, grain weight per main culm spike in the second cross. The $F_{2}$ deviation $\left(E_{1}\right)$ was accompanied by backcross deviation $E_{2}$ in thirty nine cases Table (5) and that would ascertained the presence of epistasis in such large magnitude as to warrant great deal of attention in wheat breeding programs. Also, a great deal of attention of epistasis was reported in wheat by Esmail and Khattab (2002), Darwish and Ashoush (2003) and Ghanem (2008).

\section{Nature of gene action:}

Genetical analysis of generation means to give estimates of mean effect parameter $(m)$, additive (a), dominance (d), the three epistatic types additive $\mathrm{x}$ additive (aa), additive $x$ dominance $(\mathrm{ad})$ and dominance $x$ dominance (dd) were calculated according to the relationships illustrated by (Gamble 1962). The estimated values of the various types of gene effects are presented in Table (5). Under $35 \mathrm{~kg} \mathrm{~N} / \mathrm{fed}$ nitrogen fertilization the estimated mean effects parameter $(m)$, which reflects the contribution due to the overall mean plus the locus effects and interaction of the fixed loci, were found to be highly significant for all traits in the two crosses. The additive gene effects (a) were found to be significant for days to heading, 
plant height, main culm spike, grain yield per plant and 1000 grain weight in the two crosses under investigation, number of spikes per plant in the first cross, number of spikelets per main culm spike and grain yield per main culm spike in the second cross, number of kernels in spikelets in the first cross, there is no significant in number of kernels per main culm spike, suggesting the potential for obtaining further improvements of these traits. The present results were found to agree with El-Shaarawy and Morad (2011), Koumber (2011), Dawwam et al., (2015) and Marwa. M. El-Nahas (2015).

Dominance gene effects (d) were found to be significant in the two crosses under investigation for days to heading, plant height, number of spikes per plant, main culm spike length, number of spikelets per main culm spike and number of grains per main culm spike in the two crosses under investigation, grain yield per plant, number of kernels per spikelet and grain yield per main culm spike, 1000 grains weight in second cross, suggesting that the dominance factors play a great role in the inheritance of these traits. The present results were found to agree with Menshawy (2008), El-Shaarawy and Morad (2011) and Mohammed et al., (2013).

Significant additive $\mathrm{x}$ additive (aa) epistatic types were detected for days to heading, plant height and 1000 grain weight in all crosses under investigation, main culm spike length and grain yield per main culm spike, number of spikelets per main culm spike, number of kernels per spikelet and number of kernels per main culm spike in the first cross, number of spikes per plant and grain yield per plant in the second cross. These results indicates that the materials used in this study have decreasing alleles expression for these characters and selection to improve it could not to effective expect in case of days to heading and plant height in which selection will be effective in identifying early and dwarf lines. This would be indicated by Hendawy et al. (2007 b), Hendawy et al., (2009), El-Shaarawy and Morad (2011), Koumber (2011), Morad (2012) and Marwa. M. El-Nahas (2015).

The estimated values of additive $x$ dominance (ad) types of digenic epistasis were found to be significant for days to heading in all crosses studied, plant height, number of spikelets per main culm spike and grain yield per plant in second cross 1000 grain weight in the first cross. This would be indicated by Mekhamer (2009), El-Shaarawy and Morad (2011), Kumber and El-Gammal (2012), Abd El-Rahman (2013) and Dawwam et al., (2015).

Dominance $\mathrm{x}$ dominance $(\mathrm{dd})$ epistatic types were detected to be significant for main culm spike length, number of spikelets per main culm spike, number of kernels per spikelet and grain yield per main culm spike in all crosses under investigation, days to heading and 1000 grain weight in the second cross and plant height in both crosses. Positive and significant results confirm the importance role at dominance $x$ dominance gene interaction in the genetic system controlling these characters. This would be indicated by Hendawy et al. (2007 b), Mekhamer (2009), El-Shaarawy and Morad (2011), Kumber and El-Gammal (2012), Abd El-Rahman (2013) and Dawwam et al., (2015).

It is worth to mention that the three epistatic types aa, ad and dd were found to be accompanied by significant estimates of both $E_{1}$ and $E_{2}$ epistatic scales in most traits studied and that would ascertained the presence of epistasis in such large magnitude as to warrant great deal of attention in a wheat breeding programs. Also, the heterotic effects previously mentioned could be due to both dominance and epistasis. The presence of both additive and non-additive gene action in mostly all 
traits studied would indicate that selection procedures based on the accumulation of additive effects should be successful in improving all traits under investigation. However, to maximize selection advance, procedures which are known to be effective in shifting gene frequency when both additive and non-additive genetic variances are involved would be preferred. Similar results were previously reported by Hendawy et al. (2007 b), Ghanem (2008), Mekhamer (2009), El-Shaarawy and Morad (2011), Kumber and El-Gammal (2012)) and Dawwam et al., (2015).

Under $70 \mathrm{~kg} \mathrm{~N} / \mathrm{fed}$ nitrogen fertilization, the estimated mean effects parameter $(\mathrm{m})$, which reflects the contribution due to the overall mean plus the locus effects and interaction of the fixed loci, were found to be highly significant for all traits in the two crosses. The additive gene effects (a) were found to be significant and highly significant for days to heading, plant and 1000 grains weight in all crosses, main culm spike length, number of spikelets per main culm spike and grain weight per main culm spike in the second, number of spikes per plant in the first cross only and number of grains per spikelet in the first. This would be indicated by El-Shaarawy and Morad (2011), Koumber (2011), Dawwam et al., (2015) and Marwa. M. El-Nahas (2015).

Dominance gene effects (d) were found to be significant in the two crosses under investigation for number of spikelets per main culm spike in the four crosses under investigation, days to heading and grain weight per plant in the first, second cross, plant height and main culm spike length in the first and second crosses, number of grains per main culm spike and grain weight per main culm spike in the second cross, number of spikes per plant and number of grains per spikelets in the second cross and 1000 grains weight in the second cross, suggesting that the dominance factors play a great role in the inheritance of these traits. Similar results were obtained by Menshawy (2008), El-Shaarawy and Morad (2011) and Mohammed et al., (2013).

Significant additive $\mathrm{x}$ additive (aa) epistasic types were detected for days to heading, 1000 grains weight, plant height and number of grains per spikelets in both crosses, main culm spike length in all crosses. Number of grains per main culm spike and grain weight per main culm spike in the second cross, grain weight per plant in the first cross. This would be indicated by Hendawy et al. (2007 b), Ghanem (2008), Hendawy et al., (2009), Koumber (2011) and and Marwa. M. El-Nahas (2015).

The estimated values of additive $x$ dominance (ad) types of digenic epistasis were found to be significant for days to heading and 1000 grains weight in the first cross, plant height and number of spikes per plant and main culm spike length in both crosses, number of spikelets per main culm spike in the second cross, number of grains per spikelets sand grain weight per plant in the second cross only. This would be indicated by, El-Shaarawy and Morad (2011), Koumber (2011), Kumber and ElGammal (2012), Abd El-Rahman (2013) and Dawwam et al., (2015).

Dominance $\mathrm{x}$ dominance (dd) epistatic types were detected to be significant for days to heading, number of spikes per plant and grain weight per main culm spike in the second cross, plant height, grain weight per plant and 1000 grain weight in the first cross, main culm spike length and number of spikelets per main culm spike in all crosses and number of grains per spikelets in the first and second crosses. This also founded by Hendawy et al. (2007 b), Ghanem (2008), Kumber and El-Gammal (2012), Abd ElRahman (2013) and Dawwam et al., (2015).

It is worth to mention that the three epistatic types aa, ad and dd were found to 
be accompanied by significant estimates of both $E_{1}$ and $E_{2}$ epistatic scales in most traits studied and that would ascertained the presence of epistasis in such large magnitude as to warrant great deal of attention in a wheat breeding programs. Also, the heterotic effects previously mentioned could be due to both dominance and epistasis. The presence of both additive and non-additive gene action in mostly all traits studied would indicate that selection procedures based on the accumulation of additive effects should be successful in improving all traits under investigation. However, to maximize selection advance, procedures which are known to be effective in shifting gene frequency when both additive and non-additive genetic variances are involved would be preferred. Regarded to Hendawy et al. (2007 b), Mekhamer (2009), El-Shaarawy and Morad (2011), Kumber and El-Gammal (2012), Abd ElRahman (2013) and Dawwam et al., (2015).

\section{Heritability and genetic advance:}

Heritability in both broad and narrow sense and genetic and advance under selection were computed and the obtained results are illustrated in Table (6). High heritability estimates in broad sense were detected for nearly all traits studied.

Under $35 \mathrm{~kg} / \mathrm{fed}$ nitrogen fertilization, high estimates of narrow sense heritability were found for plant height, number of spikes per plant and number of spikelets per main culm spike in all crosses under investigation, main culm spike length, grain yield per main culm spike and 1000-grain weight in the second cross only.

Under $70 \mathrm{~kg} \mathrm{~N} / \mathrm{fed}$ nitrogen fertilization, high estimates of narrow sense heritability were found for plant height, number of grains per main culm spike, grain weight per main culm spike, number of spikelets per main culm spike, grain weight per plant and
1000 grains weight in the first cross, number of grains per spikelets in the second cross only, in. Similar results were obtained by Hendawy et al. (2007 b), Ghanem (2008), Larghari et al., (2010), Koumber (2011) and El-Shaarawy and Morad (2011).

Moderate estimates of narrow sense heritability under $35 \mathrm{~kg} \mathrm{~N} / \mathrm{fed}$ nitrogen fertilization were obtained for grain weight per plant, days to heading and number of grains per spikelet in the first and second crosses, main culm spike length, number of kernels per main culm spike, grain yield per main culm spike and 1000-grain weight in the first cross, and grain yield per main culm spike in the second cross only.

Under $70 \mathrm{~kg} \mathrm{~N} / \mathrm{fed}$ nitrogen fertilization, moderate estimates of narrow sense heritability were obtained for days to heading and number of spikelets per main culm spike, number of spikes per plant, main culm spike length, number of grains per main culm spike, 1000 grains weight and grain weight per plant in the second cross. Low values of narrow sense heritability were observed for days to heading, number of spikes per plant main culm spike length and number of grains per spikelet in the first cross. The differences in magnitudes of both broad and narrow sense heritability estimates which were found for most traits under investigation would ascertained the presence of both additive and non-additive gene action in the inheritance of most traits in all crosses studied as previously obtained from gene action parameters study Table (6). This were agreed with this reported by Hendawy et al. (2007 b), Ghanem (2008), Larghari et al., (2010) and Koumber (2011).

Genetic advance under selection which are given in Table (6) show the possible gain from selection as percent increase in the $F_{3}$ over the $\mathrm{F}_{2}$ mean when the most desirable 5 $\%$ of the $F_{2}$ plants are selected. Genetic advance under selection ( $\Delta G \%$ ) was found 
Dawwam, et al.,

Table (6): Heritability estimates, genetic advanced $(\Delta \mathrm{g})$ and genetic advance expressed as a percent of $F_{2}$ means $(\Delta g \%)$ for all characters studied in the two crosses under investigation under 35 and $70 \mathrm{~kg} \mathrm{n} / \mathrm{fed}$ of nitrogen fertilization.

\begin{tabular}{|c|c|c|c|c|c|c|}
\hline \multirow{2}{*}{ Characters } & \multirow{2}{*}{$\begin{array}{l}\mathrm{Kg} \mathrm{N} / \\
\text { fed }\end{array}$} & \multirow{2}{*}{ Cross } & \multicolumn{2}{|c|}{ Heritability } & \multicolumn{2}{|c|}{$\begin{array}{l}\text { Genetic } \\
\text { advance }\end{array}$} \\
\hline & & & $\begin{array}{l}\text { Broad } \\
\text { sense }\end{array}$ & $\begin{array}{l}\text { Narrow } \\
\text { sense }\end{array}$ & $\Delta \mathrm{g}$ & $\Delta G \%$ \\
\hline \multirow{2}{*}{ Days to heading } & 35 & $\begin{array}{l}1 \\
2 \\
\end{array}$ & $\begin{array}{l}87.96 \\
78.77 \\
\end{array}$ & $\begin{array}{l}44.59 \\
47.28 \\
\end{array}$ & $\begin{array}{l}5.34 \\
5.52 \\
\end{array}$ & $\begin{array}{l}6.51 \\
6.36 \\
\end{array}$ \\
\hline & 70 & $\begin{array}{l}1 \\
2 \\
\end{array}$ & $\begin{array}{l}85.38 \\
86.27\end{array}$ & $\begin{array}{l}27.17 \\
47.00 \\
\end{array}$ & $\begin{array}{l}3.02 \\
5.32 \\
\end{array}$ & $\begin{array}{l}3.70 \\
5.93 \\
\end{array}$ \\
\hline \multirow{2}{*}{ Plant height } & 35 & $\begin{array}{l}1 \\
2 \\
\end{array}$ & $\begin{array}{l}94.19 \\
77.84 \\
\end{array}$ & $\begin{array}{l}54.44 \\
56.59 \\
\end{array}$ & $\begin{array}{l}11.77 \\
10.16 \\
\end{array}$ & $\begin{array}{l}10.08 \\
8.47 \\
\end{array}$ \\
\hline & 70 & $\begin{array}{l}1 \\
2 \\
\end{array}$ & $\begin{array}{l}90.05 \\
67.53\end{array}$ & $\begin{array}{l}58.03 \\
53.42 \\
\end{array}$ & $\begin{array}{c}11.69 \\
9.33 \\
\end{array}$ & $\begin{array}{l}9.97 \\
7.63 \\
\end{array}$ \\
\hline \multirow{2}{*}{ Number of spikes per plant } & 35 & $\begin{array}{l}1 \\
2\end{array}$ & $\begin{array}{l}83.11 \\
78.88\end{array}$ & $\begin{array}{l}52.87 \\
55.20\end{array}$ & $\begin{array}{l}2.84 \\
5.02\end{array}$ & $\begin{array}{l}47.62 \\
67.06\end{array}$ \\
\hline & 70 & $\begin{array}{l}1 \\
2\end{array}$ & $\begin{array}{l}79.98 \\
66.67\end{array}$ & $\begin{array}{l}37.13 \\
40.27\end{array}$ & $\begin{array}{l}1.83 \\
2.14\end{array}$ & $\begin{array}{l}34.10 \\
24.44\end{array}$ \\
\hline \multirow{2}{*}{ Main culm spike length } & 35 & $\begin{array}{l}1 \\
2\end{array}$ & $\begin{array}{l}86.70 \\
91.42\end{array}$ & $\begin{array}{l}47.80 \\
66.86\end{array}$ & $\begin{array}{l}1.33 \\
1.82\end{array}$ & $\begin{array}{l}11.34 \\
10.72\end{array}$ \\
\hline & 70 & $\begin{array}{l}1 \\
2\end{array}$ & $\begin{array}{l}82.53 \\
85.24\end{array}$ & $\begin{array}{l}32.90 \\
42.28\end{array}$ & $\begin{array}{c}0.835 \\
1.06\end{array}$ & $\begin{array}{l}6.83 \\
8.12\end{array}$ \\
\hline \multirow{2}{*}{ Number of spikelets / main culm spike } & 35 & $\begin{array}{l}1 \\
2\end{array}$ & $\begin{array}{l}90.15 \\
81.65\end{array}$ & $\begin{array}{l}54.14 \\
53.36\end{array}$ & $\begin{array}{l}2.12 \\
1.70\end{array}$ & $\begin{array}{l}9.73 \\
7.09\end{array}$ \\
\hline & 70 & $\begin{array}{l}1 \\
2 \\
\end{array}$ & $\begin{array}{l}88.77 \\
78.95 \\
\end{array}$ & $\begin{array}{l}55.25 \\
94.39 \\
\end{array}$ & $\begin{array}{l}2.17 \\
1.60 \\
\end{array}$ & $\begin{array}{c}10.13 \\
6.64 \\
\end{array}$ \\
\hline \multirow{2}{*}{ Number of kernels per spikelet } & 35 & $\begin{array}{l}1 \\
2 \\
\end{array}$ & $\begin{array}{l}83.90 \\
82.76 \\
\end{array}$ & $\begin{array}{l}43.82 \\
44.83 \\
\end{array}$ & $\begin{array}{l}0.852 \\
0.497\end{array}$ & $\begin{array}{l}23.02 \\
22.81 \\
\end{array}$ \\
\hline & 70 & $\begin{array}{l}1 \\
2\end{array}$ & $\begin{array}{l}82.73 \\
74.60\end{array}$ & $\begin{array}{l}32.53 \\
52.38\end{array}$ & $\begin{array}{l}0.611 \\
0.495\end{array}$ & $\begin{array}{l}16.41 \\
20.96\end{array}$ \\
\hline \multirow{2}{*}{ Number of kernels per main culm spike } & 35 & $\begin{array}{l}1 \\
2\end{array}$ & $\begin{array}{l}83.35 \\
83.15\end{array}$ & $\begin{array}{l}42.23 \\
54.43\end{array}$ & $\begin{array}{l}15.12 \\
16.40\end{array}$ & $\begin{array}{l}26.07 \\
24.50\end{array}$ \\
\hline & 70 & $\begin{array}{l}1 \\
2\end{array}$ & $\begin{array}{l}80.92 \\
80.00\end{array}$ & $\begin{array}{l}57.60 \\
45.65\end{array}$ & $\begin{array}{l}19.42 \\
13.31\end{array}$ & $\begin{array}{l}38.65 \\
19.44\end{array}$ \\
\hline \multirow{2}{*}{1000 grains weight } & 35 & $\begin{array}{l}1 \\
2\end{array}$ & $\begin{array}{l}82.00 \\
75.09\end{array}$ & $\begin{array}{l}38.56 \\
57.34\end{array}$ & $\begin{array}{c}7.59 \\
10.51\end{array}$ & $\begin{array}{l}13.11 \\
24.57\end{array}$ \\
\hline & 70 & $\begin{array}{l}1 \\
2\end{array}$ & $\begin{array}{l}93.92 \\
65.44\end{array}$ & $\begin{array}{l}56.99 \\
41.70\end{array}$ & $\begin{array}{l}11.61 \\
7.13\end{array}$ & $\begin{array}{l}19.11 \\
15.44\end{array}$ \\
\hline \multirow{2}{*}{ Grain yield per main culm spike } & 35 & $\begin{array}{l}1 \\
2 \\
\end{array}$ & $\begin{array}{l}89.56 \\
64.98 \\
\end{array}$ & $\begin{array}{l}48.57 \\
37.98 \\
\end{array}$ & $\begin{array}{c}1.03 \\
0.695 \\
\end{array}$ & $\begin{array}{l}35.48 \\
23.10 \\
\end{array}$ \\
\hline & 70 & $\begin{array}{l}1 \\
2\end{array}$ & $\begin{array}{l}82.21 \\
62.84 \\
\end{array}$ & $\begin{array}{l}67.23 \\
54.02 \\
\end{array}$ & $\begin{array}{l}1.51 \\
1.04 \\
\end{array}$ & $\begin{array}{l}49.05 \\
32.04 \\
\end{array}$ \\
\hline \multirow{2}{*}{ Grain yield per plant } & 35 & $\begin{array}{l}1 \\
2\end{array}$ & $\begin{array}{l}94.19 \\
78.04\end{array}$ & $\begin{array}{l}47.92 \\
49.01\end{array}$ & $\begin{array}{l}8.58 \\
9.59\end{array}$ & $\begin{array}{l}78.38 \\
49.98\end{array}$ \\
\hline & 70 & $\begin{array}{l}1 \\
2\end{array}$ & $\begin{array}{l}88.39 \\
76.06\end{array}$ & $\begin{array}{l}35.82 \\
35.15\end{array}$ & $\begin{array}{l}6.61 \\
6.84\end{array}$ & $\begin{array}{l}45.51 \\
32.71\end{array}$ \\
\hline
\end{tabular}


Johnson et al. (1955) reported that heritability estimates a long with genetic gain upon selection were more valuable than the former alone in predicting the effect of selection. On the other hand, Dixit et al. (1970) pointed out that high heritability is not always associated with high genetic advance, but in order to make effective selection, high heritability should be associated with high genetic gain.

In the present investigation, high genetic gain was found to be associated with high narrow sense heritability estimates for number of spikes, number of kernels per spikelet, grain yield per main culm spike, number of grains per main culm spike, grain yield per main culm spike and grain yield per plant in all crosses studied and plant height and number of kernels per main culm spike, main culm spike length and number of spikelets per main culm spike in the first cross under $35 \mathrm{~kg} / \mathrm{fed}$ nitrogen fertilization. Under $70 \mathrm{~kg} / \mathrm{fed}$ nitrogen fertilization high genetic gain was found to be associated with high narrow sense heritability estimates for grain weight per plant in the first cross. Therefore, selection for these straits should be effective and satisfactory for successful breeding proposes.

Moderate estimates of narrow sense heritability and high or moderate genetic advance were obtained for number of spikes per plant in all crosses, grain yield per plant in the first cross under $35 \mathrm{~kg} / \mathrm{fed}$ nitrogen fertilization. Under $70 \mathrm{~kg} / \mathrm{fed}$ nitrogen fertilization moderate estimates of narrow sense heritability and high or moderate genetic advance were obtained for grain weight per main culm spike in the first cross. Selection for these traits would be effective, but probably of less success than in the former characters.

Relatively low narrow sense heritability was associated with moderate or low estimates of genetic gain, 1000-grain weight in the first cross, grain yield per main culm spike in the second cross only under 35 $\mathrm{kg} / \mathrm{fed}$ nitrogen fertilization. Under $70 \mathrm{~kg} / \mathrm{fed}$ nitrogen fertilization selection for these traits would be effective, but probably of less success than in the former characters.

Relatively low narrow sense heritability was associated with moderate or low estimates of genetic gain for most traits in all crosses. Hence selection procedures for these traits would be of less effectiveness. This were agreed with this reported by Hendawy et al. (2007 b), Ghanem (2008) and Mekhamer (2009)

\section{CONCLUSION}

Studying six populations analysis showed that hybrid combination Sids $1 \mathrm{X}$ Gemmeiza 5 was detected to be the highest cross showed significant useful heterosis for grain yield per plant under both nitrogen fertilizations. The additive gene effects (a) were found to be significant for days to heading, plant height and 1000 grains weight for all crosses under investigation under the two levels of nitrogen fertilization. Dominance gene effects (d) were found to be significant in the two crosses for number of spikelets/main culm spike under $35 \mathrm{~kg} . \mathrm{n} . / \mathrm{fed}$ only. The three epistatic types additive $\times$ additive, additive $\times$ dominance and dominance $\times$ dominance were found to be significant for most traits under investigation. High genetic advance under selection was found to be associated with high narrow sense heritability estimates for number of spikes per plant and grain yield per plant.

That give chance to improve wheat in breeding programs toward increasing yield potentiality and some related characters.

\section{REFERENCES}

Abd El-Rahman, Magda E. (2013). Estimation of some genetic parameters through generation mean analysis in 
three bread wheat crosses. Alex. J. Agric. Res. 58(3): 183-195.

Akhtar, W. M. and A. M. Ibrahim (2005). Estimation of heritability of some important traits in spring wheat (Triticum aestivum L.). Caderno de Pesquisa Sér. Bio. Santa Cruz do Sul., Vol. 17, No. 1, Jan / Jun: $20-27$.

Bayoumi, T. Y. (2004). Diallel cross analysis for bread wheat under stress and normal irrigation treatments. Zagazig J. Agric. Res., 31 (2): 435-455.

Comber, R. M. (2001). Estimation of the different components of genetic variance of some quantitative traits in bread wheat. Ph.D. Thesis, Faculty of Agric., Minufiya Univ., Egypt.

Darwish, I.H.I. and H.A. Ashoush (2003). Heterosis, gene effect, heritability and genetic advance in bread wheat. Minufiya J. Agric. Res. 28(2):433-444.

Dawwam, H.A., F. A. Hendawy, M. A. Abo Shereif and E. L. El-massry (2015). Utilization of triple test cross in bread wheat $F_{2}$ populations. Genetic diversity of triple test cross families based on principal components and cluster analysis. The $9^{\text {th }}$ plant Breed. inter. conf. Egypt. J. plant Breed. 19(3):57-70.

Dixit, P. K., P. D. Saxena and L. K. Bhatia (1970). Estimation of genotypic variability of some quantitative characters in groundnut. Indian J. Agric. Sci., 40: 197 201.

El-Borhamy, H.S., M.A. El-Maghraby and A.M. Gadallah (2008). Genetic behavior of yield and its components in three bread wheat crosses. Egypt. J. Agric. Res., 86 (3): 973-984

El-Seidy, E. H. and A. A. Hamada (2000). Interaction of wheat genotypes $\times$ water sources. Proc. $9^{\text {th }}$ Conf. Agron., Minufiya Univ. Sept. 2000, pp. $17-34$.

El-Shaarawy, G. A. and A. A. Morad (2011). Genetic studies on some bread wheat crosses. Minufiya J. Agric. Res. Vol. 36 No.4: 981 - 996.
Esmail, R. M. and S. A. M. Kattab (2002). Genetic behaviour of yield and its components in three bread wheat crosses. Minufiya J. Agric. Res., 27 (2): $215-224$.

Gamble, E.E. (1962). Gene effects in corn (Zea mays L.). 1. Separation and relative importance of gene effects for yield. Can. J. Plant Sci.42:339-348.

Ghanem, W.M. (2008). Genetic analysis of grain yield and other quantitative characters in some crosses of bread wheat (Triticum aestivum L.) Ph.D. Thesis, Faculty of Agric., Minufiya Univ., Egypt.

Hendawy, F. A., H. A. Dawwam and Mona M. Serag EI-Din (2007b). The detection of the different components of variation in bread wheat (Triticum aestivum L.). Minufiya J. Agric. Res., 32 (4):1071 1086.

Hendawy, F. A., H. A. Dawwam, M.A. Abo Shereif and E. L. El- Massry (2009). Detection of epistasis in the inheritance of grain yield and its components in bread wheat (Triticum aestivum L.) using triple test cross analysis. Minufiya J. Agric. Res., Vol.3 No.2: 625-640.

Johnson, H. W., H. F. Robinson and R. E. Comstock (1955). Estimates of genetic and environmental variability in soybean. Agron. J., 47: 314-338.

Ketata H., E. L. Smith, E. L. Edwards and R. W. Mc. New. (1976). Detection of epistasis, additive and dominance variation in winter wheat (Triticum aestivum L.). Crop Sci., 16: 1 - 4.

Koumber, R. M. A. (2011). Estimation of genetic parameters for some quantitative traits in two bread wheat crosses (Triticum aestivum, L.). Minufiya J. Agric. Res. Vol. 36 No.2: 359 - 369.

Koumber, R.M. and A.A. El-Gammaal (2012). Inheritance and gen action for yield and its attributes in three bread wheat crosses (Triticum aestivum L.). 
World Journal of Agricultural Sciences, 8 (2): 156-162.

Larghari, K. A., M. A. Sial, M. A. Arain, A. A. Mirbahari, A. J. Pirzada, M.U. Dahot and S.M. Mangrio (2010). Heritability studies of yield and yield associated traits in bread wheat. Pak. J. Bot., 42(1): 111-115

Marani, A. (1968). Heterosis and inheritance of quantitative characters in interspecific crosses of cotton. Crop. Sci. 8:299-303.

Marwa. M. El-Nahas (2015). Using triple test cross analysis to estimate genetic components, prediction and genetic correlation in bread wheat Inter. J. Micro. App. Sci., 4(11):79-87.

Marwa, M. El-Nahas and S. A. Arab (2014). Estimation of genetic variance components in two bread wheat crosses. Minufiya J. Agric. Res. 39 No. 3(1):989998.

Mather, K. (1949). Biometrical Genetics. Dover publications, Inc., London.

Mather, K. and J.L. Jinks (1982). Biometrical Genetics.3rdEd. Chapman and Hall, London.

Mekhamer, K. I. S. (2009). Inheritance of some important agronomic traits in common wheat. Ph.D. Thesis, Faculty of Agric. Moshtohor Benha Univ., Egypt.

Menshawy, A.M.M. (2008). Estimation of gene action and predictin new recombination lines in bread wheat cross using F2 triple test cross analysis. Egypt J. Agric. Res., 86(5), 1905-1920

Miller, P. A., J. C. Williams, H. F. Robinson and R. E. Comstock (1958). Estimates of genotypic and environmental variances and covariances in upland cotton and their implications in selection. Agron. J., 50:126-131.

Mohammed, S. Hassan, R. A.R. El-Said and S.H.M. Abd-El-Halee (2013). Estimation of heritability and variance components for some quantitative traits in bread wheat (Triticum aestivum I.). World Appl. Sci. J., 27 (8): 944-949

Morad, A.A. (2012). Epistasis, genetic correlation and prediction of new recombinations in wheat using $F_{2}$ triple test crosses. J. Agric. Res. Kafr El-Sheikh Univ. 38 (4): 471-488

Peter, F.C. and K. J. Frey (1966). Genotypic correlation, dominance and heritability of quantitative characters in Oats. Crop. Sci., 6: 259-262.

Sharief, A.E., M.H. El Hinidi, M.S. Sultan, A.H. Abdel El Latif and M.N. El- Hawary (2006). Heterosis in some bread wheat crosses under normal and water stress conditions. Egypt J. Plant Breed.10 (2):114.

Singh, S. (1981). Single tester triple test cross analysis in spring wheat. Theoretical and Applied Genetics 59: 247-249.

Singh, S. and R. B. Singh (1976). Triple test cross analysis in two wheat crosses. Heredity, 37 (2): $173-177$.

Singh, R. P. and S. Singh (1992). Estimation of genetic parameters through generation mean analysis in bread wheat. Indian Journal of Genetics, 52: 369-375. 
تحديد وتقدير المكونات المختلفه للتباين الوراثى (المضيف، السيادى والتفوقى) تحت الظروف

البيئيه القاسيه والعاديه في قمح الخبز التئ

1- تقدير مكونات التباين الوراثى في هجينين من قمح الخبز تحت مستويين

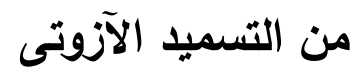

حسان دوام(1)، فتحى هنداوى(1) ، محروس عبد الغنى(2) ، منى محمد محمد سراج الدين(1) - جادئ

(1) قسم المحاصيل - كلية الزراعة - جامعة المنوفية - مصر

(2) قسم بحوث القمح - مركز البحوث الزراعية - مصر

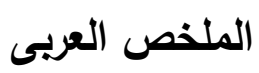

تهدف هذه الدراسة الى معرفة قوة الهجين ودرجة السيادة والسلوك الوراثي ودرجة التوريث والتحسين الوراثي المتوقع بالانتخاب وطبيعة الفعل الجيني لصفات المحصول ومكوناته في هجينين من القمح هما الأول (سدس 1 هـ جميزه 5) والثاني (جميزه 9 × سدس 4) وذلك تحت مستوبين من التسميد الازوتى هي 35 كجم ازوت / فدان، 70 كجم ازوت / فدان وذلك باستخدام موديل العشائر الستة وقد أجري البحث في مزرعة كلية الزراعة بشبين الكوم جامعة المنوفية في ثلاث مواسم منتالية هي (2010/2009، 2011/2010، 2012/2011). وكانت الصفات الددروسة هي: ميعاد طرد السنابل (يوم) - طول النبات (سم) - عدد السنابل بالنبات - طول سنبلة الساق الرئيسيه (سم) - عدد السنيبلات بالساق الرئيسيه - عدد الحبوب بالسنيبله - عدد حبوب السنبلة - وزن 1000 حبه - محصول سنبلة الساق الرئيسيه (جم) - محصول النبات (جم).

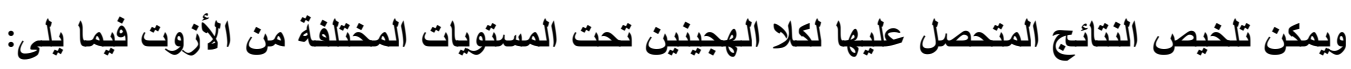
1- أظهر الهجين (سنس 1× جميزه 5) اعلى قوة هجين لصفة محصول النبات حيث كانت 37.5\% و

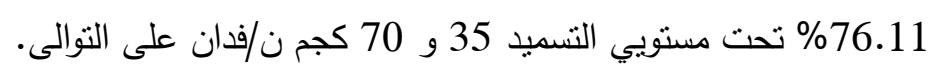

2- وجد ان الانخفاض الناتج عن التربيه الداخليه عالى المعنويه في معظم الحالات في الهجينين تحت الدراسه. 3- كان مقياس التفوق E1 معنويا لطول النبات وعدد السنيبلات في سنبلة الساق الرئيسيه لكل الهجن تحت مستويي التسميد. كذلك كان مقياس التفوق E2 معنويا لميعاد الطرد، طول سنبلة الساق الرئيسيه وعدد الحبوب بالسنيبله تحت مستويي التسميد النيتروجيني. 4- كانت تأثثر الجينات من النوع المضيف معنويا لصفات ميعاد الطرد، طول النبات ووزن 1000 حبه لجميع

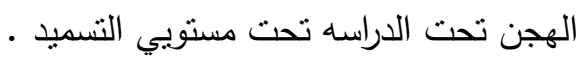
5- كانت تأثير الجينات من النوع السيادى معنويا لصفة عدد سنيبلات السنبله الرئيسيه لجميع الهجن تحت الدراسه

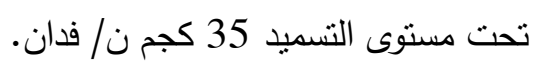

6- كان فعل الجينات التفوقى بطرزه الثلاثة (المضيف × المضيف) و (المضيف × السيادي) و (السيادي × السيادي) معنويا لمعظم الصفات المدروسة في كلا الهجينين تحت مستويات النتروجين المختلفة. 


\section{Dawwam, et al.,}

7- كانت قيمة درجة التوريث بمعناها العام عالية لمعظم الصفات المدروسة بينما كانت الكفاءة الوراثية بمعناها الدقيق عاليه بالنسبة للميعاد الطرد ، طول السنبلة ، عدد السنابل بالنبات ، طول سنبلة الساق الرئيسيه ، عدد الحبوب للسنيبله، عدد حبوب سنبلة الساق الرئيسيه ومحصول النبات تحت مستوى التسميد المنخفض. 8- كانت القيم العالية للتحسين الوراثي المنوقع بالانتخاب مصاحبه للقيم العالية لدرجة التوريث بالمعنى الدقيق لصفة عدد السنابل بالنبات و محصول النبات لجميع الهجن تحت المستوى المنخفض من التسميد الازوتى. 9- وجد ان المعالم الوراثيه الناتجه من الهجين الثانى أعلى من المتحصل عليها من الهجين الآخر. وعليه يمكن التوصيه باستخدام الهجين سدس 1× جميزه 5في برامج التربيه خاصة البرامج التى تعتمد على التهجين والانتخاب (الانتخاب المتكرر) وكذلك برامج التربيه للظروف البيئيه القاسيه حيث انه اظهر تفوقا عالى لهيه المعنويه في أغلب الصفات خاصة صفة المحصول والصفات المرتبطه به تحت مستويى التسميد العادى و المنحفض.

البريد الالكترونى

E-mail:mujareg@gmail.com 

Dawwam, et al., 